\title{
EVALUATION OF SOME NATURAL SUBSTANCES FOR CONTROLLING VARROA DESTRUCTOR AND THEIR EFFECTS ON INDIVIDUAL ACTIVITY OF HONEYBEE COLONIES.
}

Abou El-Enain, H. T. ${ }^{1}$; M. A. Ali ${ }^{2}$ and A. A. Eissa ${ }^{1}$

1- Honeybee Research Department, Plant Protection Research Institute, Agriculture Research Centre.

2- Plant Protection Department, Faculty of Agricultural, Ain Shams Univ.

\begin{abstract}
The present work was carried out at branch Beekeeping Research Department at Qalubia governorate. The aim of investigation evaluate the efficacy of some local natural substances for controlling Varroa destructor in honeybee colonies and their comparison with Apiguard $25 \%$ Thymol as material import was recommended. The result obtained show that, the mean reduction of infection with Varroa mite could be arranged into the following descending orders as follows: $86.78 \%, 81.48 \%, 79.33 \%$, $75.33 \%$ and $68.96 \%$ when using plates Apiguard, Crystal Thymol, mixture of (Thymol, Menthol and Camphor), and Menthol, respectively. The experimental colonies were treated with ( 2-plates /colony) one plate at fortnight for (4 weeks). The mean increase of treated honeybee colonies for controlling Varroa mite was $7.96 \%$ and $67.69 \%$ for both brood rearing and honey production as compared to that of untreated colonies.

Generally, it could be concluded that, in cas of infestation of honeybee colonies with Varroa mite it is advisable to use Apiguard substance, Crystal Thymol and a mixture of (Thymol, Menthol and camphor). At the rate of one plate/ 2 weeks/ colony for (4weeks) at high temperature greater than $27^{\circ} \mathrm{C}$.
\end{abstract}

\section{INTRODUCTION}

The parasitic mite Varroa destructor (Anderson and Truemane, 2000) is the most devastating pest affecting in honeybee (Apis mellifera $L$.) colonies worldwide. Varroa damage immature and adult bees by feeding on bee hemolymph and also by transmitting harmful viruses.

In the past years, the primary chemicals has been the pyrethroide fluvalinate, followed by the organophosphate and then by formic acid. Each compound has negative associated with their use. It is impact has been compounded because these Varroa mites quickly became resistance to the chemicals fluvalinate (Elzen et al., 1998, 2000). Research on alternative chemical controls such as formic acid thymol has shown some promising results Feldloufer et al. (1997) and Mattila et al. (2000) but problems such as the effect of temperature on the timing of application, variable efficacy results, labor costs and the need for multiple applications have showed the advancement of these control methods for beekeeper use. Many products both chemical and natural are currently used in the control of this mite infestation. Among these products, different components of the essential oils were tested in laboratory and in particular, thymol (5-methyl- 2-(1- methyl ethyl) phenol) demonstrated the highest Varroa cidal activity at concentration well tolerated by the bees (Imdorf et al. 1995). The Varroacidal activity of 
thymol was experimented not only in laboratory assays, but also in field in Europe (Imdrof et al. 1999) and in North America (Ellis et al. 2001, Melathopoulos and Gates 2003). Different dosages, ways and times of application have been tested on colonies in the post, often reporting highly satisfactory results (range of mean effectiveness 66-99.5\%) Imdrof et al. (1999). Emara et al. (1994) Concerned with the formulation and evaluation of certain plant extracts for controlling varroa mites.

Thymol, which is a volatile monoterpenoid and a natural constituent of thyme (Thymus vulgaris) is widely used in honeybee colonies as a treatment against Varroa (Gregorc and Jelenc 1996; Imdorf et al. 1999). Thymol residues, which can be found in the honey after treatments, do not affect its taste if applied following the harvest (Bogdanov et al. 1998). Apiguard (Vita Europe Ltd., Basingstoke, England), which comes in gel form, is a registered Thymol-based fumigant that is used against Varroa mites in honeybee colonies. The present work aimed to evaluate of some natural substances for controlling Varroa destructor and their effects on activity of honeybee colonies.

\section{MATERIALS AND METHODS}

The present work was carried out at branch Beekeeping Research Department at Qalubia governorate is that administration, Agriculture Research Center. The aim of investigation evaluate the efficacy of some local natural substances for controlling Varroa destructor in honeybee colonies and their comparison with Apiguard $25 \%$ thymol as material import was recommended.

\section{1- Preparation of the experimental colonies:}

Eighteen honeybee colonies first hybrid Carniolan were infested with Varroa mite, the experimental colonies were divided into six groups each composed of three colonies, relatively similar strength, colonies in each group were insignificant of infested with Varroa mite in adult. The treatment of experiment was carried out from winter season, 2005 to clover season, 2006.

\section{2- Preparing the natural substances:}

Such groups were treated as follows:

Group (A): Apiguard on the shape plates of aluminum as material import was recommended (vita Europe limited), which contained $50 \mathrm{~g}$ gel, $25 \%$ thymol.

Group (B): Crystal thymol 25\%, which was prepared on the shape plates from aluminum foil as follow: A mixture of $50 \mathrm{~g}$ of talc powder + Vaseline (as carrier material) containing $25 \%$ thymol (12.5g) and put in aluminum foil inside Petri dish as past form.

Group (C): Menthol 25\% which was prepared on the shape plates from aluminum foil as follow: A mixture of $50 \mathrm{~g}$ of (talc powder + Vaseline) containing $25 \%$ Camphor oil $(12.5 \mathrm{~g})$ and put in aluminum foil inside Petri dish as past form. 
Group (D): Camphor 25\% which was prepared on the shape plates from aluminum foil as follow: A mixture of $50 \mathrm{~g}$ of (talc powder + Vaseline) containing $25 \%$ Camphor (12.5g) and put in aluminum foil inside Petri dish as past form.

Group (E): A mixture of natural product (Camphor + Menthol + Thymol) which was prepared on the shape of plates from aluminum foil. The plate was prepared as a mixture of $50 \mathrm{~g}$. of talc powder + Vaseline containing $25 \%$ of mixture natural product $(12.5 \mathrm{~g}$.) as a ratio $4.17 \mathrm{~g}$. of each.

The Thymol and Camphor were obtained from El Gomhouria Co. whereas the six Menthol was obtained from El Nasr Pharmacutical chemicals Co. Abou Zabal.

Group (F): untreated colonies (Control).

The plates were placed on the top of board facing the brood chamber after open cover the plate to allow the bees to enter the plate and remove the product.

The colonies of experimental colonies were treated with (2 plates /colony) one plate at fortnight. The total treatment period was four weeks from the beginning of the fourth week of December 2005 till the end of the third week of January, 2006. The honeybee colonies were fed on sugar syrup $(66.6 \%$ Conc.) one /week. The bottom board of the hive was covered with a plastic sheet coated with raw Vaseline to capture the fallen mites. The died Varroa mites were counted and removed at the end of each treatment. The day temperature and relative humidity were recorded daily allover the experiment.

\section{3- Determination of Varroa infestation: \\ a- On workers:}

The percent infestations of Varroa mite on workers before and after treatments were determined according to Komeili (1988) Accordingly, samples of hundred bees/ colony were collected randomly in vial partially filled with water containing few drops of detergent. The samples were shaken and the bees were washed in a strainer, individual mites that fell off from worker bees were found at the bottom of the white container (Ritter, 1981). All worker bees and mite were counted for each sample, where the number of mites / 100 workers was calculated.

\section{b- In brood cells:}

The infestation percent of Varroa mites in brood cells was determined by using forty five worker cells that were opened and the Varroa mite occurring with these cells were counted. Reduction percentage in mite infestation was calculated according to Henderson and Tilton (1955).

\section{4- Effects of tested materials:}

a- On individual honeybee colonies:

After treatment of the experimental colonies, the average daily of queen and adult bees were counted until the end of experimental, also odour and disturbance of honeybee colonies were observed compared with untreated colonies. 
b- On brood rearing activity:

The daily worker sealed brood cells was counts after treated honeybee colonies at 13 day intervals, on December 22, 2005 until March, 22, 2006.

c- On clover honey production:

The clover honey produced by test colonies was evaluated for each colony individually as a difference between the weight of bee honey combs before and after extraction in clover season 2006.

\section{RESULTS AND DISCUSSION}

\section{1- Effect of the natural substances against Varroa mite:}

Table (1) and Fig. (1) Show that, the Apiguard (Vita Europe limited) caused reduction of infestation being $85.27 \%$ and $88.29 \%$ for brood cells and adult, respectively. The mean reduction of infestation reached $86.78 \%$ for both brood and adult. Crystal Thymol on the shape plates as past form caused reduction of infestation being $76.93 \%$ and $86.03 \%$ for brood cells and adult, respectively. The mean reduction of infestation reached $81.48 \%$ for both brood and adult.

Menthol on the shape plates as pest form caused reduction of infestation being $66.83 \%$ and $71.08 \%$ for brood cells and adult, respectively. The mean reduction of infestation reached $68.96 \%$ for both brood and adult. Camphor on the shape plates as past form, caused reduction of infestation being $71.15 \%$ and $79.51 \%$ for brood cells and adult, respectively. The mean reduction of infestation reached $75.33 \%$ for both brood and adult.

Mixture of (Thymol, Menthol and camphor) on the shape plates as past form caused reduction of infestation being $75.87 \%$ and $82.79 \%$ for brood cells and adult, respectively. The mean reduction of infestation reached $79.33 \%$ for both brood and adult.

Table (1): Reduction percentages of Varroa mites on brood and adult honeybee.

\begin{tabular}{|c|c|c|c|c|c|c|c|}
\hline \multirow[b]{2}{*}{ Treatments } & \multicolumn{2}{|c|}{$\begin{array}{l}\text { \%Infestation in } \\
\text { brood cells }\end{array}$} & \multirow[b]{2}{*}{$\begin{array}{c}\% \\
\text { Reduction }\end{array}$} & \multicolumn{2}{|c|}{$\begin{array}{l}\text { \%Infestation } \\
\text { on adult bees }\end{array}$} & \multirow[b]{2}{*}{$\begin{array}{c}\% \\
\text { Reduction }\end{array}$} & \multirow[b]{2}{*}{ Mean } \\
\hline & $\begin{array}{c}\text { Before } \\
\text { treat. }\end{array}$ & $\begin{array}{l}\text { After } \\
\text { treat. }\end{array}$ & & $\begin{array}{c}\text { Before } \\
\text { treat. }\end{array}$ & $\begin{array}{l}\text { After } \\
\text { treat. }\end{array}$ & & \\
\hline Apiguard $25 \%$ thymol & $\begin{array}{c}32.0 \\
\pm 2.31\end{array}$ & $\begin{array}{r}5.33 \\
\pm 1.33\end{array}$ & 85.27 & $\begin{array}{l}25.12 \\
\pm 3.62\end{array}$ & $\begin{array}{c}3.61 \\
\pm 1.41\end{array}$ & 88.29 & 86.78 \\
\hline Crystal thymol $25 \%$ & $\begin{array}{l}30.67 \\
\pm 3.53\end{array}$ & $\begin{aligned} & 8.0 \\
\pm & 2.31\end{aligned}$ & 76.93 & $\begin{array}{l}23.38 \\
\pm 2.72\end{array}$ & $\begin{array}{c}4.01 \\
\pm 1.52\end{array}$ & 86.03 & 81.48 \\
\hline Menthol 25\% & $\begin{array}{r}32.0 \\
\pm 4.61 \\
\end{array}$ & $\begin{array}{r}12.0 \\
\pm 2.33\end{array}$ & 66.83 & $\begin{array}{l}26.67 \\
\pm 3.85\end{array}$ & $\begin{array}{c}9.47 \\
\pm 2.72 \\
\end{array}$ & 71.08 & 68.96 \\
\hline Camphor $25 \%$ & $\begin{array}{l}38.33 \\
\pm 2.31 \\
\end{array}$ & $\begin{array}{l}10.87 \\
\pm 3.33 \\
\end{array}$ & 71.15 & $\begin{array}{l}24.69 \\
\pm 3.79 \\
\end{array}$ & $\begin{array}{c}6.21 \\
\pm 1.71 \\
\end{array}$ & 79.51 & 75.33 \\
\hline $\begin{array}{c}\text { 25\%Mix. of(Camphor + } \\
\text { Thymol + Menthol) }\end{array}$ & $\begin{array}{l}29.33 \\
\pm 3.53 \\
\end{array}$ & $\begin{array}{r}8.0 \\
\pm 2.31 \\
\end{array}$ & 75.87 & $\begin{array}{l}29.01 \\
\pm 2.63 \\
\end{array}$ & $\begin{array}{r}6.13 \\
\pm 1.77 \\
\end{array}$ & 82.79 & 79.33 \\
\hline Untreated & $\begin{array}{l}30.67 \\
\pm 4.09\end{array}$ & $\begin{array}{l}34.67 \\
\pm 3.53\end{array}$ & -- & $\begin{array}{l}21.09 \\
\pm 3.19 \\
\end{array}$ & $\begin{array}{l}25.89 \\
\pm 3.47 \\
\end{array}$ & -- & -- \\
\hline
\end{tabular}

2- Fallen Varroa mite in honeybee colonies:

Table (2) indicated that, treating Varroa mites infesting honeybee colonies with the tested material caused significantly higher number of fallen 
Varroa mites as compared to that of untreated colonies. Mean total of fallen Varroa (788 mites) was recorded after using plate of Apiguard followed by crystal thymol on the shape plates (768 mites), mixture of (Thymol, Menthol and camphor) on the shape plates (566 mites), Camphor on the shape plates (496 mites) and Menthol on the shape plates (485 mites). The least number of fallen Varroa was recorded in untreated colony (84 mites). It can be concluded that, the number of dead fallen mites were increased gradually in case of using natural materials, this might be due to slow action against Varroa mite.

From the results obtained in Table (3) and Fig (1) it could be concluded that, the reduction of infection could be arranged into the following descending orders as follows: Apiguard plates, Crystal thymol plates, mixture of (Thymol, Menthol and Camphor) plates, Camphor plates and Menthol plates for both brood cells and adult.

Table (2): Number of fallen Varroa mites after daily sequence from the treatments.

\begin{tabular}{|c|c|c|c|c|c|c|c|c|}
\hline \multirow{2}{*}{ Treatments } & \multicolumn{7}{|c|}{ Mean number of fallen Varroa mites after treatment } & \multirow[t]{2}{*}{ Total } \\
\hline & 1 & 2 & 3 & 7 & 14 & 21 & 28 & \\
\hline Apiguard $25 \%$ thymol & $\begin{array}{c}273 \\
\pm 6.24\end{array}$ & $\begin{array}{c}152 \\
\pm 15.3\end{array}$ & $\begin{array}{c}129 \\
\pm 11.79\end{array}$ & \begin{tabular}{|c|}
133 \\
\pm 8.95 \\
\end{tabular} & $\begin{array}{c}69 \\
\pm 14.11\end{array}$ & $\begin{array}{c}25 \\
\pm 6.17\end{array}$ & $\begin{array}{c}7 \\
\pm 1.55\end{array}$ & 788 \\
\hline Crystal thymol $25 \%$ & $\begin{array}{c}196 \\
\pm 9.17\end{array}$ & \begin{tabular}{|c|}
168 \\
\pm 19.12
\end{tabular} & $\begin{array}{c}114 \\
\pm 14.52 \\
\end{array}$ & $\begin{array}{c}183 \\
\pm 11.85\end{array}$ & $\begin{array}{c}60 \\
\pm 7.86\end{array}$ & $\begin{array}{c}36 \\
\pm 8.12\end{array}$ & $\begin{array}{c}11 \\
\pm 1.78\end{array}$ & 768 \\
\hline Menthol 25\% & $\begin{array}{c}141 \\
\pm 5.17\end{array}$ & $\begin{array}{c}87 \\
\pm 12.51 \\
\end{array}$ & $\begin{array}{c}91 \\
\pm 7.18 \\
\end{array}$ & $\begin{array}{r}105 \\
\pm 10.81 \\
\end{array}$ & $\begin{array}{c}39 \\
\pm 8.74 \\
\end{array}$ & $\begin{array}{r}10 \\
\pm 3.18 \\
\end{array}$ & $\begin{array}{r}12 \\
\pm 1.72 \\
\end{array}$ & 485 \\
\hline Camphor 25\% & $\begin{array}{c}98 \\
\pm 9.49\end{array}$ & \begin{tabular}{|c|}
121 \\
\pm 12.5
\end{tabular} & \begin{tabular}{|c|}
95 \\
\pm 6.19 \\
\end{tabular} & $\begin{array}{c}66 \\
\pm 10.9 \\
\end{array}$ & $\begin{array}{c}93 \\
\pm 16.12 \\
\end{array}$ & \begin{tabular}{|c|}
16 \\
\pm 5.29 \\
\end{tabular} & $\begin{array}{c}7 \\
\pm 1.53 \\
\end{array}$ & 496 \\
\hline $\begin{array}{l}25 \% \text { Mix. of (Camphor + } \\
\text { Thymol + Menthol) }\end{array}$ & $\begin{array}{c}161 \\
\pm 11.21\end{array}$ & \begin{tabular}{|c|}
85 \\
\pm 9.14 \\
\end{tabular} & \begin{tabular}{|c|}
131 \\
\pm 12.15 \\
\end{tabular} & $\begin{array}{c}61 \\
\pm 7.25 \\
\end{array}$ & $\begin{array}{c}82 \\
\pm 9.51 \\
\end{array}$ & \begin{tabular}{|c|}
37 \\
\pm 6.11 \\
\end{tabular} & $\begin{array}{c}9 \\
+2.14 \\
\end{array}$ & 566 \\
\hline Untreated & $\begin{array}{c}8 \\
\pm 1.73 \\
\end{array}$ & \begin{tabular}{|c|}
10 \\
\pm 1.78 \\
\end{tabular} & \begin{tabular}{|c|}
9 \\
\pm 1.21 \\
\end{tabular} & $\begin{array}{r}14 \\
\pm 4.33 \\
\end{array}$ & \begin{tabular}{|c|}
12 \\
\pm 5.19 \\
\end{tabular} & $\begin{array}{r}15 \\
+2.64 \\
\end{array}$ & \begin{tabular}{|c|}
16 \\
\pm 3.36 \\
\end{tabular} & 84 \\
\hline
\end{tabular}

Generally, a thymol product should be applied when the treatment ranges between $18.5^{\circ} \mathrm{C}$ and $27^{\circ} \mathrm{C}$. This results similarity with Imdorf et al (1995).

It is advisable to use Apiguard, Crystal thymol, Menthol, Camphor and mixture of (Thymol, Menthol and Camphor) on the shape plates on strong colony at high temperature greater than $27 \stackrel{\circ}{\circ} \mathrm{C}$ enhance the distribution of thymol in the hive through ventilation but it was recommended not to use on weak colonies at high temperature greater than $18.5^{\circ} \mathrm{C}$ this results coincide with Alessandra et al (2004).

Table (3): Natural substances in descending orders for $\%$ reduction of adult and brood honeybee.

\begin{tabular}{|c|c|c|c|c|c|c|}
\hline Individual & Apiguard & $\begin{array}{c}\text { Crystal } \\
\text { Thymol }\end{array}$ & $\begin{array}{c}\text { Mix. of Camphor++ Camphor } \\
\text { Thymol+Menthol }\end{array}$ & Menthol & L.S.D. \\
\hline Adult & 88.29 & 86.03 & 82.79 & 79.51 & 71.08 & 8.14 \\
\hline Brood & 85.27 & 76.93 & 75.87 & 71.15 & 66.83 & 9.12 \\
\hline
\end{tabular}

3- Effect of tested substances on odour and individual colony status:

As shown in Table (4) show that, there was no effect of tested substances on odour and individual colony statues as compared to that of untreated colonies. 
Abou El-Enain, H. T. et al.

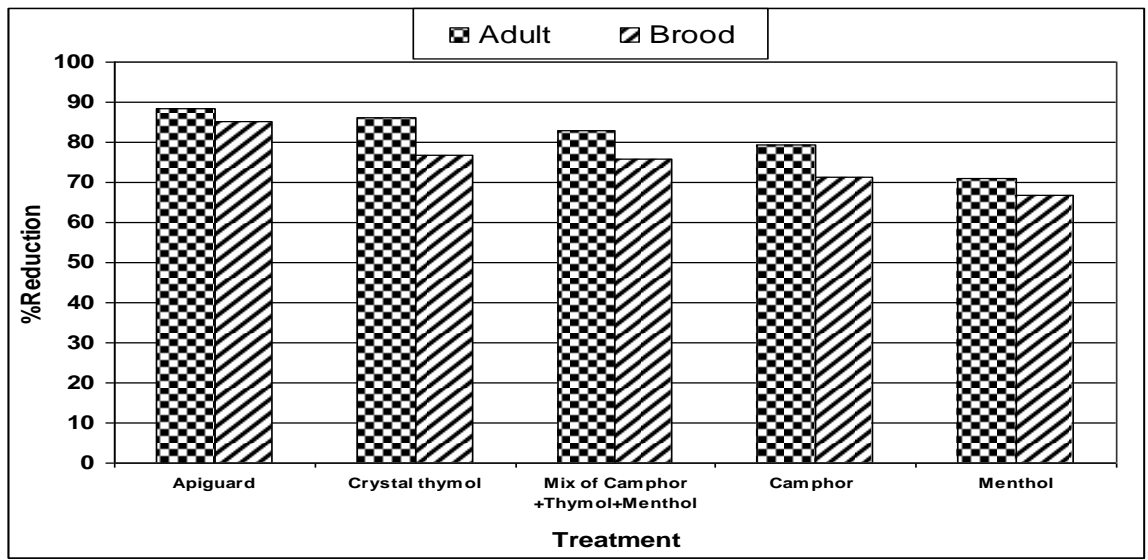

Fig. (1): Efficiency of some natural substances in controlling Varroa mite on adult and brood honeybees.

4- Effect of tested substances on worker sealed brood cells:

From the results obtained in table (4), the highest average daily worker brood cells was 478.38 cells with increase of $13.18 \%$ when using Apiguard, followed by 472.46 cells with increase $11.77 \%$ when using thymol, 457 cells with increase $8.12 \%$ when using mixture of (Thymol, Menthol and Camphor), 439.38 cells with increase $3.95 \%$ when using menthol and 434.46 with increase $2.78 \%$ when using Camphor, respectively.

\section{5- Effect of tested substances on honey production:}

As shown in Table (4), the highest average of honey production was $6 \mathrm{~kg}$. With increase $84.62 \%$ as compared to that untreated colonies when using mixture of (Thymol, Menthol and Camphor) for controlling Varroa mites, followed by $5.75 \mathrm{~kg}$. with increase $76.92 \%$ when using Thymol, $5.5 \mathrm{~kg}$ with increase $69.23 \%$ when using Apiguard, $5.25 \mathrm{~kg}$. with increase $61.54 \%$ when using Camphor and $4.75 \mathrm{~kg}$ with increase $46.15 \%$ as compared to that untreated colonies when using Menthol for controlling Varroa mites.

Table (4): Effect of tested substances on individual colony status, brood rearing activity and honey production on honeybee colonies.

\begin{tabular}{|l|c|c|c|c|c|c|}
\hline \multicolumn{1}{|c|}{ Treatments } & $\begin{array}{c}\text { No of } \\
\text { queenless }\end{array}$ & $\begin{array}{c}\text { Average } \\
\text { daily of adult } \\
\text { bees died } \\
\text { after treat. }\end{array}$ & $\begin{array}{c}\text { Average } \\
\text { daily of } \\
\text { sealed brood } \\
\text { cells after } \\
\text { treat. }\end{array}$ & $\begin{array}{c}\% \\
\text { increase } \\
\text { of sealed } \\
\text { brood }\end{array}$ & $\begin{array}{c}\text { Clover } \\
\text { honey } \\
\text { production } \\
\text { (kg) }\end{array}$ & $\begin{array}{c}\% \\
\text { increase } \\
\text { of honey }\end{array}$ \\
\hline Apiguard 25\% thymol & 0.0 & $2.93 \pm 0.121$ & $478.38 \pm 32.08$ & 13.18 & $5.5 \pm 0.55$ & 69.23 \\
\hline Crystal thymol 25\% & 0.0 & $3.9 \pm 0.101$ & $472.46 \pm 33.0$ & 11.77 & $5.75 \pm 0.61$ & 76.92 \\
\hline Menthol 25\% & 0.0 & $4.04 \pm 0.181$ & $439.38 \pm 28.38$ & 3.95 & $4.75 \pm 0.71$ & 46.15 \\
\hline Camphor 25\% & 0.0 & $4.0 \pm 0.14$ & $434.46 \pm 31.92$ & 2.78 & $5.25 \pm 0.86$ & 61.54 \\
\hline $25 \% M i x$. of (Camphor + & 0.0 & $3.06 \pm 0.16$ & $457.0 \pm 30.62$ & 8.12 & $6.0 \pm 0.75$ & 84.62 \\
\hline Thymol + Menthol) & 0.0 & 3.59 & 456.34 & 7.96 & 5.45 & 67.69 \\
\hline Mean & 0.0 & $4.37 \pm 0.191$ & $422.69 \pm 36.38$ & 0.0 & 3.25 & 0.0 \\
\hline Untreated & & & & & & \\
\hline
\end{tabular}


There was no effect of natural tested substances on physical shape, color and odour of harvest honey, it is preferred advice to use of natural tested substances for controlling Varroa mites in winter and after the honey harvest. This results coincide with Mattilla and Otis (2000).

\section{Acknowledgement}

My thanks are due to Prof. Dr. A. G. El-Sisi, Prof. in Laboratory Center Pesticides, Agric. Res. Center for my help in preparation used in this study

\section{REFERENCES}

Alessandra, B.; P. Arculeo;A. Nanetti; E. Marinelli and F. Mutinelli (2004): Field trials with different thymol-based products for the control of Varroosis. Amer. Bee J., 144: 395-399.

Anderson, D. L. and J.W. H. Trueman (2000): Varroa jacobsoni (Acri: Varroidea) is more than one species. Experimental and Applied Acarology, 24: 165-189.

Bogdanov, S., Kilchenmann, V., Imdrof, A. and P. Fluri (1998): Residues in honey after application of thymol against Varroa using the Fracno Thymol Frame, Amer. Bee J., 138: 610-611.

Ellis, J. D. jr; K. S. Delaplane and M. Hood (2001): Efficacy of a bottom screen device, Apistan, and Apilife VAR, in controlling Varroa destructor. Amer. Bee J., 141: 813-816.

Elzen, P. J.; F. A. Eichen; J. R. Baxter; J. Pettis; G. W. Elzen and W. T. Wilson (1998): Fluvalinate resistance in Varroa jacobsoni from several geographic locations. Amer. Bee J., 138: 674-676.

Elzen, P. J.; J. R. Baxter; M. Spivak and W. T. Wilson (2000): Control Varroa jacobsoni Oud. Resistant to fluvalinate and amitraz using coumaphos. Apidologie, 31: 437-441.

Emara, M.M.; A.G., El-Sisi; Soheir, A.M. (1994): Formulation and evaluation certain local natural productsagainst Varroa mites infesting colonies. J. Agric. Sci., Mansoura Univ.,19(5):1843-1850.

Feldlaufer, M. F.; J. S. Pettis; J. P. Kochansky and H. Shimanuki (1997): A gel formulation of formic acid for the control of parasitic mites of honeybees. Amer. Bee J. 137: 661-663

Gregorc, A. and J. Jelenc (1996): Control of Varroa jacobsoni oud. In honeybee colonies using Apilife-Var. Zbornik Veterinarske Fakultete, Univerza v Ljubjani, 33: 231-235.

Henderson, C.F. and E.W. Tilton (1955): Test with acaricides against the brown wheat mite. J. Econ. Entomol., $48: 157-161$.

Imdorf, A.; S. Bogdanov; V. Kilchenmann and C. Maquelin (1995): Apilife VAR: a new varroacide with thymol as the main ingredient. Bee world 76: 77-83.

Imdorf, A.; S. Bogdanov; R. I. Ochoa and N. Calderone (1999): Use of the essential oils for the control of Varroa jacobsoni Oud. in honeybee colonies. Apidologie 30: 209-228. 


\section{Abou El-Enain, H. T. et al.}

Komeili, A.B. (1988): The impact of the Varroa mite on Iranian commercial beekeeping. Amer. Bee J., 128: 423-424.

Mattila, H. R. and G. W. Otis (1999): Trials of Apiguard, a thymol-based miticide. Part1. Efficacy for control of parasitic mites and residue in honey. Amer. Bee J., 139: 947-452.

Mattila, H. R. and G. W. Otis (2000): The efficacy of Apiguard against Varroa and tracheal mites, and its effect on honey production: 1999 trial. Amer. Bee J., 140: 969-973.

Mattila, H. R. ; G. W. Otis; J. Daley and T., Schulz (2000): Trials of Apiguard, a thymol-based miticide. Part 2. Non-target effect on honeybees. Amer. Bee J. 140: 68-70.

Melathopolous, A. P. and J. Gates (2003): Comparison of two thymol-based acaricides, Apilife VAR and Apiguard, for the control of Varroa mites. Amer. Bee J. 143: 489-493.

Ritter, W. (1981): Varroa disease of the honeybee Apis mellifera. Bee world, 62(4): 141-153.

\section{تقييم بعض المواد الطبيعية في مكافحة طفيل الفاروا وتاثيرها علي افراد وانشطة

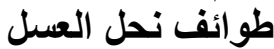

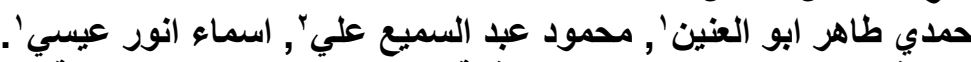

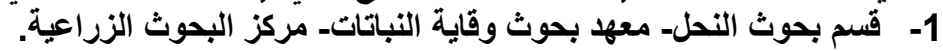

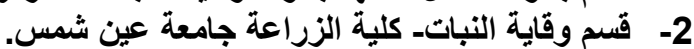

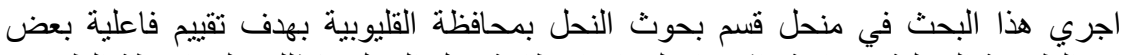

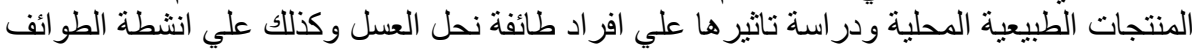

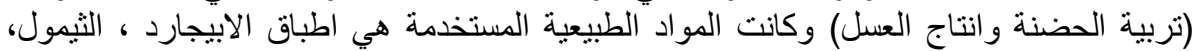

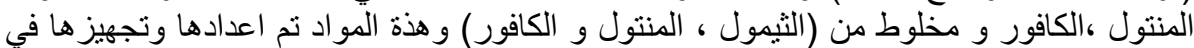

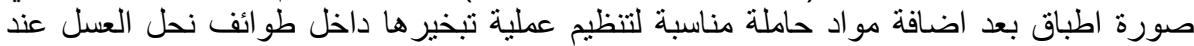
الاستخدام.

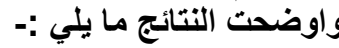

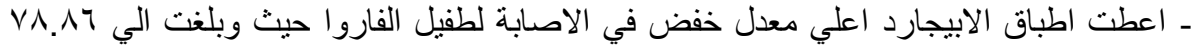

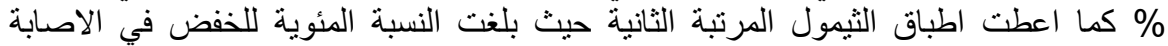

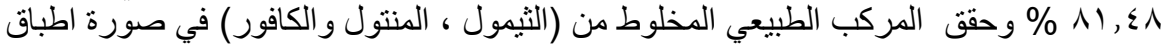

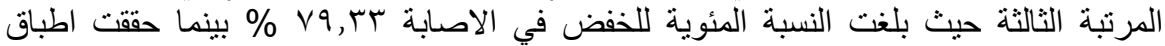

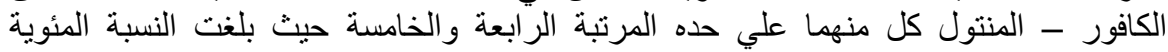

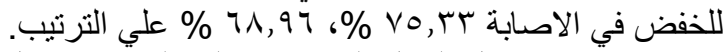

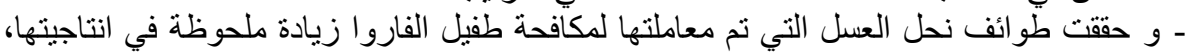

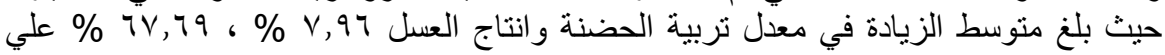

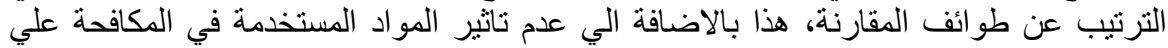

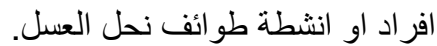

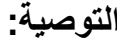

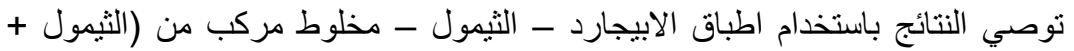

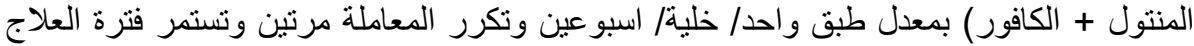

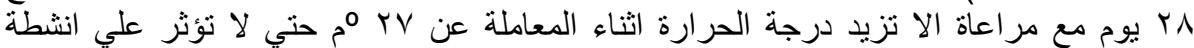

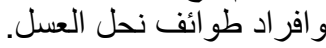

